\title{
We believe in life before death: the Christian aid movement in Taiwan, 1970-78
}

\begin{abstract}
Christian Aid, a faith-based anti-poverty charity based in the UK, origins lie in the reconstruction of Europe following the Second World War. In 1948, the organisation regrouped under the title: Inter-Church Aid and Refugee Service and its focus shifted towards worldwide poverty. The 1970s saw the organisation directly funding over 100 development projects in 40 different countries and by the 1990s Christian Aid was campaigning on global political issues that included (but not limited to) South African apartheid, Stop Climate Chaos, fair trade and trade justice movements. Without representatives overseas, Christian Aid works entirely through local structures, mainly churches and/or voluntary organisations; relying heavily on regional screening of projects by local experts. The collection used in this paper comprises of correspondences, minutes and reports. It draws on primary sources material (in both English and Chinese) that include: the Taroko Mountain Village Development Programme in 1973; the typhoon relief in 1973-74; Leadership and Community Development for East Coast Aborigines in 1972; the Training Centre for Handicapped People (est. 1972-73); Health Education Programme for East Coast Aborigines (1970-72); Social Service Centre (1970-71); Lotung Student Centre (1974-75); Vehicle repairing courses for tribal people, 1972-76; Aboriginal Agricultural Development Project-1975-76; among others. The paper is framed in the context of civil movements (in particular relief programmes), with the Taiwan indigenous peoples as a representative case study. Its main contribution is as a historical source; a comparative for present-day civil movements that have their routes in grassroots issues. In the case of Taiwan, much of the literature on the 1970s has tended (and perhaps rightfully so) concentrated on the change in representation at the United Nations Security Council in 1971; the US establishment of diplomatic ties with the Peoples' Republic of China (PRC) in 1972; the passing of the Taiwan Relations Act in '1979; the 1979 Kaohsiung Incident; and the death of Chiang Kaishek and power transfer to Chiang Ching-kuo in ' 75 and '78 respectively. Little is known on social movements and development projects among the indigenous peoples during this 'decade of change'. By addressing this overlooked aspect of the history of Taiwan civil movements, this paper will greatly contribute to existing knowledge on social movements, rights discourses and citizenship.
\end{abstract}

Keywords: civil movements, taiwan indigenous peoples, christian aid, relief programmes, aid

\section{Introduction}

Isn't there something that the mountain people can grow on the mountain sides that cannot be grown anywhere else, giving them a 'monopoly' on that product which would bring up their living standard quickly? William E Siemens (Program Director, Taroko Community Development Program 1971). ${ }^{1}$ We want to use our traditional law (gaga) to talk about the (Smangus, simakusi Smarcus) case. It is not because we broke the law. That tree fell over in typhoon. We put it by the side of the road for more than a month. The Forestry Bureau took away the good wood. We work as a cooperative. We had a village meeting. We arranged for three people to go and collect the rest of the tree. After that we met some officials. Then we went to meet with the Forestry Bureau. They said we stole the wood, we are thieves. When they said this we were very unhappy, because we didn't steal the wood. We just wanted to use it in the village. Village Chief (Figure $1)^{2,3}$

${ }^{1}$ CA3/A/PAC/19, Taiwan 09 Health Education Programme for East Coast Aborigines-1970-1972: Taroko Community Development Program 1971 Year End Report (1971).

${ }^{2}$ David Reid. Indigenous Rights in Taiwan and the Smangus Case. MA diss., National Chengchi University; 2010. 54 p.

${ }^{3}$ Permission to use this photograph was granted by Christian Aid.
Volume 3 Issue 2 - 2018

Niki Alsford
Faculty, University of Central Lancashire, UK

Correspondence: Niki Alsford, Faculty, University of Central Lancashire, UK, Email na29@soas.ac.uk

Received: March 20, 2018| Published: April 24, 2018 
"Whether I should wear clothes or this way that's none of your business nobody can interfere me [sic]." ${ }^{4}$ These words, written as a caption to a photograph, were perhaps not an articulation of the picture's protagonist, but rather a later addition. He, an unnamed middle-aged man from the Yami (or Tao) indigenous group on Orchid Island (Lanyu), is shown wearing only a simple loincloth. The background highlights village life: recently caught flying fish hang out to dry against the backdrop of a pristine mountain landscape and the Pacific Ocean extending beyond. Just off-center, the man has been 'photobombed' by a young, naked, inquisitive boy, collectively capturing one moment in their lives. Almost a month earlier andrew Chang, Chairman of the Orchid Island Project, had written in a letter to Rev. Kentaro Buma, Secretary for Asia at the Commission on InterChurch Aid in Geneva: "Under 30 degree temperature on Orchid Island these April days, almost 1,000 adults prefer their naked way of life for fishing and farming. A month ago, a donor (Japanese doctor) contributed US \$200 through us to buy clothes for the children of four local elementary schools and one junior high school. They were very happy; however, their parents abhor education and "a different way" influenced by outsiders. The beliefs and traditions they have practiced [sic] for centuries are being overthrown by those who are educated. They feel there is less security and prestige among the older people." ${ }^{5}$

This statement reveals a big issue concerning the general conduct towards cultural references and sensitivities, one pertinent to the discourse on social and civic movements, both past and present. That is the frequency of the collective voice of a movement to inadvertently silence the voices of those on whose behalf they are campaigning. Despite good intentions, the collective action of the movement often speaks for, rather than giving voice to, the very person or group for whom it campaigns. In the letter quoted above, the author begins by suggesting, perhaps incorrectly, that he understood that their choice of attire was a preference made due to temperature and while accepting this custom for adults felt it was inappropriate for children at school. He then continues, in an almost Orwellian doublethink manner, by being empathetic to their concerns of "outside" influences. The letter continues: "In this transition period, the leadership training, based on Christian ethics to esteem aged people, to eliminate some superstitions and to teach them the Christian view of life is very necessary. Every month we hold meetings for groups of the older folks, deacons and elders. We also provide kindergarten and Sunday school teacher training. For younger persons, we add some recreational activities and provide Christian books to stimulate and develop Christian thinking [sic] In the sphere of the community life, instead of Government housing projects (Government offer materials and techniques and the people cooperate by bringing gravel and same for building construction), the people on Orchid Island still prefer living in oldfashioned dug-out cavernous caves. The heavy moisture causes much suffering with skin diseases, articular rheumatism and asthma. They also suffer with head lice and body fleas. We want to cooperate with the Government sanitary system to improve drainage and disposal of sewage and a pure water supply to help the people live in a good hygienic, healthy condition."

These gross over-generalizations based on stereotypes reduce the people of Orchid Island to a pitiful collection of symptoms. In a comparative, cross-cultural perspective, there is little, if anything,

${ }^{4} \mathrm{CA} / \mathrm{A} / \mathrm{PAC} / 19$, Taiwan 12 Orchid Island Project: Photograph caption (25 May 1972).

${ }^{5} \mathrm{CA} 3 / \mathrm{A} / \mathrm{PAC} / 19$, Chang to Buma (18 April 1972). ${ }^{6}$ Ibid. that is unique or distinctive in the manner in which the movement to "improve the lives of the Orchid Islanders" is presented. A simple search on charitable movements in the developing world will instantly discover clear buzzwords, such as "education" "environment" and "healthcare." In most cases, there is no denying that such social movements have a profound effect upon the lives of those that they are helping. But when do aid and charitable organizations traverse the boundaries of rights movements? Using material deposited in the School of Oriental \& African Studies (SOAS), University of London's Archives \& Special Collections and this chapter intends to draw particular attention to the development and relief projects initiated by Christian Aid in Taiwan during the 1970s. In doing so, this chapter will contribute to an expanding literature on social and civil movements in Taiwan by highlighting the local structures (namely church-based voluntary organizations) upon which Christian Aid relied heavily in the absence of any formal representatives. In turn, these local experts give a wider nuance to the social and political issues of the period. As an organization, the origins of Christian Aid (a faith-based antipoverty charity based in the UK) lie in the reconstruction efforts of post-war Europe. In 1948, three years after the end of the Second World War, the organization regrouped under the title: Inter-Church Aid and Refugee Service and its focus shifted towards global poverty.

The 1970s have been chosen as the chapter's focus for two reasons. Firstly, the decade witnessed an increase in the organization's funding to cover more than 100 development projects in 40 countries. It had, by the 1990s, also campaigned on global political issues that included, among others, apartheid in South Africa, the 'Stop Climate Chaos' coalition, fair trade and trade justice-many of the same social issues addressed by contemporary Taiwanese civil society. Secondly, the decade became a critical juncture in Taiwan's political history. In 1971 Taiwan (as the Republic of China) was replaced by the People's Republic of China (PRC) as a permanent member of the United Nations Security Council and as the representative of China in the UN assembly. Other key events included the death of Chiang Kai-shek and the transfer of power to his son, Chiang Ching-kuo, in 1975 and 1978 respectively and in 1979 the passing of the Taiwan Relations Act in 1979, as well as the Kaohsiung Incident. Finally, by examining this period in the social history of Taiwan it is possible to identify subtle similarities between the civil movements of the past two decades and the regional screening movements carried out by Christian Aid in the 1970s. This approach allows a focus on the details of the individuals involved in their everyday lives and it is here that the social structures of these predominately church-based social movements and their ideologies interact. Only on this level is it possible to see how the movement was put into practice and how it was affected by political change.

\section{Social movements in Taiwan since 2000}

The last two decades in Taiwan have seen a remarkable transformation in civic and social movements. ${ }^{7}$ It has, as Ming-sho Ho argues, "been an integral dimension of democratization in Taiwan." Social protest, particularly from the "disadvantaged sectors" farmers, labor and marginalized ethnic minorities has been a powerful force

${ }^{7}$ Fan Yun, Shuogushi yu minzhu taolun: yige gongmin shehui neibu zuqun duihua luntan de fenxi, Storytelling and Democracy Discussion: An Analysis of the Internal Communities Dialogue Forum in Civil Society [Story-telling and Democratic Discussion: An Analysis of Ethnic Dialogue Workshop in Civil Society]. Taiwan Democracy Quarterly, 2010;7(1):65-105.

${ }^{8}$ Ming-sho Ho. Taiwan's State and Social Movements under the DPP Government 2000-2004. Journal of Asian Studies 2005;5:401. 
in the changing political landscape of which Taiwan-based social movements have been part. Work, of course, still remains in assessing the impact that democratization has had on social movements in Taiwan, as Stephen Phillon correctly alludes to in his article on social movements and Taiwan's democracy. ${ }^{9}$ As such, it is not in the ambit of this chapter to contribute to this particular debate. Suffice it to say that many areas that specific social movements address do have a direct link to democratization. Ming-sho Ho's research focused on the three social movement cases, Involving labor, environment and education reform. And although they had different tenets, all used mass demonstrations to pressure government. ${ }^{10}$ It is with such cases that the concerns of charitable organizations such as Christian Aid are similar.

Before engaging with the social movements of the last two decades, it is important to clarify certain phrasing. In the context of this chapter, social movements are interpreted as a type of group action, namely a grouping of individuals whose focus is on specific social and/or political issues, with their intention being to resist, execute or work against social change. Different academic disciplines emphasize a variety of empirical research with differing theoretical analyses. Political science papers place a greater emphasis on the relationship between popular movements and political parties, ${ }^{11}$ whereas scholars of anthropology and sociology may seek to focus on the dynamics and origin of such movements and their economic, class, gender and/ or ethnic characteristics. ${ }^{12}$ Civic movements on the other hand, tend to be more transnational: a connection, so to speak, of a series of movements associated towards equality before the law. These include, though are not limited to, the rights of minorities, women's rights and LGBTQ rights. ${ }^{13}$ Christian Aid and their local voluntary structures were social enterprises with the intention of generating social change and progress, whether that was economic, institutional, behavioral and/or natural (in relation to the environment). The present drive to understand social and civic movements in Taiwan comes largely from the energetic behavior of the Sunflower Student Movement (taiyanghua xueyun Sun Flower Movement). The movement, a coalition of student and civic groups, protested the "black box" (without clause-by-clause review) approach to the passing of the Cross-Strait Service Trade Agreement (CSSTA) by the ruling party and from 18 March and 10 April 2014, occupied the Legislative Yuan (lifayuan Legislature) and later the Executive Yuan (xingzhengyuan Executive Court). ${ }^{14}$ The movement, according to J Michael Cole, was

${ }^{9}$ Stephen Phillon, The Impact of Social Movements on Taiwan's Democracy, Journal of Current Chinese Affairs 2010;39(3):150

${ }^{10} \mathrm{Ho}$, Ming-sho Ho. Weakened State and Social Movement: The paradox of Taiwanese environmental politics after the power transfer. Journal of Contemporary China. 2005;14(43):339-40.

${ }^{11}$ See Dafydd Fell. Government and Politics in Taiwan. London: Routledge, 2012. p. 177-78.

${ }^{12}$ Tseng Yu-chin, Isabelle Cheng, Dafydd Fell. The Politics of the Mainland Spouses" Rights Movement in Taiwan. In: Chiu Kuei fan, Dafydd Fell, Lin Ping, editors. Migration to and From Taiwan. London: Routledge; 2014. p. $205-66$.

${ }^{13}$ For a selective sample see, Jens Damm, Same Sex Desire and Society in Taiwan, 1970-1987 The China Quarterly 181 (2005): 67-81; and Doris T. Chang, Women's Movements in Twentieth-Century Taiwan (Chicago, IL: University of Illinois Press, 2009).

${ }^{14}$ Lin Nansen, Taiwan shushiwan minzhong zongtongfu qian shiwei fanfumao, [Hundreds of thousands protesters gathered against the Cross-Strait Service Trade Agreement outside of the Taiwan Presidential Office] (30 March 2014) http://www.bbc.co.uk/zhongwen/trad/china/2014/03/140330 taiwan protest an instance where politically oriented movements in Taiwan took on a civic rather than an ethnic hue. ${ }^{15}$

This was previously most notable in the demonstrations in Dapu Tai Po and Huaguang, both of which involved many of the same student members who were found occupying the lifayuan. On 28 June 2010, Liu Cheng-hung (Miaoli County Commissioner) gave an evacuation order for farmland in Dapu village without notifying the resident farmers. ${ }^{16}$ Despite the efforts of the Dapu Self-Help Organization (Dabu zijiuhui Tai Po Self-help Society), the county government continued its forced land appropriation to make way for the Jhunan Science Park (Zhunan kexue yuanqu-Zhunan Science Park). On 3 August, a 73 year-old farmer, Mrs. Chu Feng-min committed suicide by drinking herbicide. What followed was a statement by thenPremier Wu Den-yih demonstrating a complete lack of sympathy: "I understand this woman suffers from chronic disease, maybe even depression, so I don't know the reason for her suicide regardless, I am very sorry." Residents and their supporters, including students and academics, were outraged by this callousness and demonstrated in front of the Presidential Office. ${ }^{17}$

Grassroots and student protests against land takeovers took place again in 2013 following forced evictions and demolition of houses at the Huaguang Community in Taipei. Cole aptly sums up the background to the protest in his blog The Far-Eastern Sweet Potato: "To make a long story short, through [sic] some of the residents of Huaguang have lived there for more than half a century, the land reportedly belongs to the central government, which means that they have been occupying it illegally. Although previous administrations had chosen not to enforce the law, the Ma Ying-jeou government earlier this year decided it could no longer wait and moved in swiftly, presumably because of the tremendous pressure it must have been receiving from land developers. The government's handling of the dispute has been awful at best, with the MOJ filing multimillion-NT-dollar lawsuits against the impoverished and elderly residents for illegally profiting from the land, seizing a portion of their bank accounts and charging them for the demolition of their homes (it also allegedly charged the residents NT $\$ 500$ per police officer that had to be deployed to the site during a pervious [sic] protest). Many of the residents are in their eighties and of ill health; some are not entitled to social assistance and most cannot afford to pay the rent in the limited social housing made available, on a priority basis to them. The community is broken, with old friends losing their homes and friends, as they are dispersed in places as far away as Nangang and Wanfang." 18

${ }^{15}$ J. Michael Cole, Say Goodbye to "Peaceful Unification" The Diplomat (1 April 2014). Accessed 8 September 2014, http://thediplomat.com/2014/04/ say-goodbye-to-peaceful-unification/

${ }^{16}$ Lin Nansen, Taiwan dapu zhengdian mianlin qiangchai, [Residential houses in Dapu, Taiwan to be forcibly demolished] (7 July 2014) http://www.bbc. co.uk/zhongwen/trad/taiwan_letters/2013/07/130707_taiwan_land

${ }^{17}$ Ketty Chen, Dapu Villagers" Protest - Three Years Later, The Participant Observer: Soaking and poking - between inside and outside 5 July 2013, http:// theparticipantobserverblog.blogspot.co.uk/2013/07/dapu-villagers-protestthree-years-later.html

${ }^{18}$ J. Michael Cole, Huaguang and the Dance of Modernity, The Far-Eastern Sweet Potato: Asian politics, with a strong focus on Taiwan 24 April 2013, http://fareasternpotato.blogspot.co.uk/2013/04/huaguang-and-dance-ofmodernity.html Also, Ketty Chen, Farewell March for Huaguang Community, The Participant Observer: Soaking and poking - between inside and outside 29 August 2013, http://theparticipantobserverblog.blogspot.co.uk/2013/08/ farewell-march-for-huaguang-community.html 
One notable feature of the Huaguang community protests is that the evicted residents were part of a last remaining mainlander refugee community in Taipei. ${ }^{19}$ The students involved in rallying support for them, thus in many ways crossed traditional party lines to align more on civic issues of equality than on the traditional "ethnic" divisions of waishengren Provincials and benshengren Provincial people that have, in the past, dominated Taiwan's political and social movement scene. ${ }^{20}$

In addition, over the past four to five years, Taiwan has witnessed a massive increase in conservationist advocacy. ${ }^{21}$ For example, 2011 saw pro-dolphin and anti-pollution campaigning, the latter championing calls for Ma Ying-jeou to condemn plans for a $\$ 30$ billion offshore petrochemical refinery. ${ }^{22}$ In his comparative study of Taiwan and China, Yanqi Tong places environmentalism as a social movement dependent on the interaction of three factors:

i. the movement being shaped by the broader political constraints and their opportunities, unique to the national context;

ii. organizational resources (such as informal networks, religious groups and voluntary associations) must be made available to mobilize people into collective action

iii. The social construction of the collective process must give meaning and value to collective action by bringing shared meaning and definition to the situation. ${ }^{23}$

In March 2011, this "interaction of three factors" with reference to environmentalism came to a head following the Fukushima Daiichi nuclear disaster in Japan, when 2,000 people in Taiwan demonstrated for an immediate end to the island's construction of a fourth nuclear power plant. The event was repeated the following year with similar numbers and was also attended by scores of indigenous protesters demanding immediate removal of nuclear waste stored on Orchid Island. ${ }^{24}$ Then in March 2013, 68,000 protesters from across the island converged against continued construction of the fourth plant and the integrity of the existing three. ${ }^{25}$ Then less than a month following

${ }^{19} \mathrm{Ho}$ Yi, Refugees "Squatting" on a Gold Mine, Taipei Times (03 July 2013), 12.

${ }^{20}$ Ming-sho Ho, The Resurgence of Social Movements under the Ma Yingjeou Government: A political opportunity structure perspective, in Political Changes in Taiwan under Ma Ying-jeou: Partisan conflict, policy choices, external constraints and security challenges, eds., Jean-Pierre Cabestan and Jacques deLisle (London: Routledge, 2014. p. 100-119.

${ }^{21}$ Yeh Chia Tsung, Huang Shu-Li, Liu Hsiou Lan. Shengtai zuji,yongxu fazhan yu taiwan nongdi baoyu, [Ecological Footprint, Sustainable Development, and Preservation of Taiwan's Agriculture Land]. City and Planning. 1999;26(2):189-208.

22 Ralph Jennings, Tipping Point for Taiwan's Environmental Movement, Forbes (17 December 2013), http://www.forbes.com/sites/ ralphjennings/2013/12/17/tipping-point-for-taiwans-environmentalmovement/

${ }^{23}$ Tanqi Tong, Environmental Movements in Transitional Societies: A comparative study of Taiwan and China, Comparative Politics 2005;37(2):169. ${ }^{24} \mathrm{On}$ nuclear waste on Lanyu, see Jackson Hu, Retrieving Ancestral Power from the Landscape: Cultural struggle and Yami ecological memory on Orchid Island, In: David Blundell, editor. Taiwan since Martial Law. Berkeley, CA \& Taipei: University of California and National Taiwan University Press; 2012. p. $183-210$

${ }^{25}$ Ming-sho Ho, The Fukishima Effect: Explaining the resurgence of the antinuclear movement in Taiwan, Environmental Politics (2014):1-19; Yu-Huay Sun, Taiwan Anti-Nuclear Protests May Derail \$8.9 Billion Power Plant, the occupation of the Lifayuan by the Sunflower Movement, social movements, supported by Lin Yi-hsiung, a political prisoner during martial law who had begun an indefinite hunger strike, mobilized to force the government to cease construction of the plant. ${ }^{26}$ With development in terms of economic growth being a marked preference over environmental issues for most political parties in Taiwan, environmentalists are frequently sidelined by business lobbying, despite gaining access to policy decision-making. ${ }^{27}$ An excellent example of this is the National Alliance for the Rescue of the Tamsui River (Quanmin qiangjiu danshuihe xingdong lianmeng National Action for the Rescue of Freshwater Rivers) whose members campaigned against Executive Yuan approval for a highway along the north shore of the Tamsui River. In 2000 the Environmental Protection Administration, EPA (huanjingbaohu shu Environmental Protection Agency) managed to halt its construction on the grounds that it would damage the local ecosystem..$^{28}$ The context of the environment, or the natural, was (and still is ${ }^{29}$ ) an important countenance of Christian Aid and their local voluntary structures. The following section will look at a number of "improvements" projects carried out in Taiwan through the assistance of Christian Aid.

\section{Charity is the opium of the privileged: $:^{30}$ christian aid and its local systems}

In the absence of a formal delegation, Christian Aid sponsored the efforts of local voluntary structures. In Taiwan the bulk of this fell to Taiwan Christian Services caituan faren Taiwan jidujiao fulihui Incorporated Taiwan Christian Welfare Association (TCS) and the Presbyterian Church. On 3 November 1969, Mr. BJ Dudbridge (Deputy Director of Christian Aid) wrote to Miss Jenny Chen (a social worker in the department of nutrition and health education at TCS) to confirm that Christian Aid had agreed to fund the distribution of Strong Arm High Protein Biscuits in Taiwan. What was more, he confirmed an interest in the Hsiu-lin [Xiulin] Mountain Community Development Project, but since Christian Aid was already funding two other community-led projects in Taiwan, they would on this occasion be unable to assist. What he did offer was that from 1970, Christian Aid would allocate funds to support the Ilan County Leadership and Community Development Project $(\$ 10,822)$ and the East Coast Aboriginal Leadership and Community Development Project $(\$ 7,697)$, in addition to supporting a social service center for indigenous communities and a rural health education and sanitation project on the east coast. ${ }^{31}$

The Xuilin project proposed by TCS was inaugurated in March 1969 as a self-help cooperative project to improve the socio-economic

Bloomberg (11 March 2013) http://www.bloomberg.com/news/2013-03-11/ taiwan-anti-nuclear-protests-may-derail-8-9-billion-power-plant.html and Ming-sho Ho, The Politics of Anti-Nuclear Protest in Taiwan: A case of partydependent movement (1980-2000), Modern Asian Studies 37:3(2003):683708 .

${ }^{26}$ J. Michael Cole, Taiwan Rocked by Anti-Nuclear Protests, the Diplomat. (28 April, 2014).

${ }^{27}$ Ho (2005), 341.

${ }^{28}$ See, Simona Grano and Ping-lan Tu, Development Vs. Environment in Taibei, Journal of Current Chinese Affairs 41:2(2012):130-33.

${ }^{29} \mathrm{CA}$. Improving the Environment in Rashah (February 2013) http://www. christianaid.org.uk/whatwedo/partnerfocus/improving-the-environment-inrashah.aspx.

${ }^{30}$ Chinua Achebe, Anthills of the Savannah (London: Heinemann, 1987).

${ }^{31} \mathrm{CA} 2 / \mathrm{C} / 13 / 10$ Williams to Chen (3 Nov 1969). 
status of local people in the villages close to Taroko Gorge. The project was divided into 12 sections with activities ranging from sewing classes, insect control, farm produce processing, health education, prenatal care and first-aid courses. ${ }^{32}$ What is clear is that in the early 1970s, nutritional and dietary supplementation became the chief concern for the both the TCS and Christian Aid. On 11 March 1970, Miss Jenny Chen received a correspondence from Celia Williams, (the administrative assistant to the deputy director of Christian Aid) regarding Strong Arm protein biscuits. ${ }^{33}$ Known principally today as the "And Everyone Ate and had enough" campaign, providing access to nutritional food was always an established principle for Christian Aid. ${ }^{34}$ During the Kosovo War (1998-1999), British charities, including Christian Aid, intensified their efforts to raise their disaster-relief activities. A Christian Aid spokesperson at the time, Sarah Stewart, told the Guardian newspaper that the charity had "sent 21 tones of high protein biscuits using trucks flown to Tirana from Copenhagen." ${ }^{35}$ A similar shipment was again repeated during the Haiti Earthquake in 2010, where enough protein biscuits were sent to feed 60,000 families. ${ }^{36}$ A simple search on other major disaster and relief efforts would probably unearth similar stories. The primary initiative thus taken by the UK charity was the provision of a bulk supply of protein biscuits and on 2 September 1970, sixty-three cases of biscuits arrived in Keelung. ${ }^{37}$

One major component of any charitable aid is the distribution of funds for the purpose of improving health. The situation in Taiwan in the 1970s was no exception. The TCS in early 1970 began the construction of a rehabilitation center for Blackfoot sufferers. Blackfoot disease (BFD) was an endemic peripheral vascular disease caused by drinking arsenic-contaminated groundwater. ${ }^{38}$ In late 1969, a weekly service was initiated to treat BFD sufferers. ${ }^{39}$ For 25 years, Dr. Wang King-ho had worked tirelessly to abate the disease among patients around Beimen, Xuejia, Budai and Yizhu. Wang, who was born on 23 April 1916 in Beimen Township, studied at Tainan's Chang Jung High School before going to Japan for further education. In 1941, he graduated from Tokyo Medical School and the following year married Mao Be Mei [Mao Bimei]. After Dr. Wang's two-years as a surgeon at Ohkubo Hospital in Tokyo, the couple moved back to Taiwan during the height of the Pacific War in order to look after his sick mother. ${ }^{40}$

${ }^{32} \mathrm{CA} 2 / \mathrm{C} / 13 / 10$ Taiwan Christian Service: Hsiu-lin Mountain Community Development Project (c.1969).

${ }^{33} \mathrm{CA} 2 / \mathrm{C} / 13 / 10$ Williams to Chen (11 March 1970).

${ }^{34} \mathrm{CA}$, And Everyone Ate and Had Enough: Lent Food, Recipes for change (2014), http://www.christianaid.org.uk/Images/lent-food-resource-book tcm15-75409.pdf

${ }^{35}$ Vickram Dodd, British Charities put on United Front in Attempt to Raise $£ 14.5 \mathrm{~m}$ The Guardian (5 April 1999)

${ }^{36}$ Vanessa Barford, Haiti Earthquake - how do UK charities help? BBC News (Saturday 16 January 2010) http://news.bbc.co.uk/1/hi/uk/8462054.stm

${ }^{37} \mathrm{CA} 2 / \mathrm{C} / 13 / 10$ Chen to Williams (2 September 1970).

${ }^{38} \mathrm{BFD}$ was found in south-western Taiwan up to the 1990 s, see: Hsin-Su Yu, Blackfoot Disease and Chronic Arsenism in Southern Taiwan International Journal of Dermatology 23:4(1984):258-60; and Chin-Hsiao Tseng, Blackfoot Disease and Arsenic: A never-ending story Journal of Environmental Science and Health, Part C: Environmental carcinogensis and ecotoxicology 23:1(2005):55-74.

${ }^{39}$ Its clinic, the former Tainan Beimen Clinic, has since been preserved as a memorial house dedicated to efforts made to eradicate the disease.

${ }^{40}$ Wang King-ho (oral history), recorded by Lin Shuangbu. Cexie wangjinhe: taiwan wujiaobinghuan zhi fu de shengming diandi, [Sketching Wang King-ho: Life of the father of the Taiwanese black-foot disease patients]. (Taipei: Grass Roots Press, 2009).
Wang began work at the Provincial Tainan Hospital where he became acquainted with the Presbyterian Church and was introduced to Dr. Hsieh Wei [Xie Wei] and Mrs. Lilian Dickson (founder of the Mustard Seed Mission: a medical and social-service mission, established in 1954 , to extend mission work to the mountainous and remote regions of Taiwan). Together they began work in the treatment of BFD. ${ }^{41}$

The Christian Aid sponsored service broadened to include other social welfare projects including family planning and a mothers' club. The latter provided a twice-weekly meeting to discuss infant care, hygiene and cooking..$^{42} \mathrm{An}$ added initiative also introduced at the time was Project 2.69 (or the Pu Tai Community Development Centre). Based on Chaiyi (central Taiwan), Pu Tai secured an assistance and cooperation from the Chaiyi county government and the Tainan Presbytery to assemble "a medical team of Christian doctors to provide a medical treatment for local people every Sunday." The medicine needed for the clinic was provided by TCS, which had also assigned one nurse and three assistants. Aside from its medical services, $\mathrm{Pu}-$ Tai in their mission statement provided the following account: "Pu Tai Chen of Chia Yi Hsien [Chiayi County] is generally known as the area where most of the black foot patients live. The inhabitants of this area gain their income mainly from fishing, salt making and farming. However, as fishing is mostly in the nearby sea, the profit is not very high. Salt production is a government monopoly. The caustic soil and shortage of water for irrigation explains why not much of a harvest could be expected from farming. Because of the very poor natural resources available to the local people, their income is very meager and only sufficient to support a family with the lowest daily necessities. As a consequence, the standare [sic] of living of this area is generally far below average." $" 43$

In addition to the standard welfare provisions provided by $\mathrm{Pu}$ Tai, the development center also operated to provide families with pre-school education, family planning and guidance and support to patients with BFD and polio, in addition to its other services. In order to improve the quality of water (reducing arsenic content to standard levels) the TCS installed a water filter tower and piping. ${ }^{44}$ Medical assistance to local Taiwanese communities also aimed at reaching the indigenous communities situated within the mountain ranges and along the east coast. ${ }^{45}$ On 11 March, 1970, the MacKay Memorial Hospital in Taipei confirmed receiving gifts from the United Church of Canada, "Wild Geese" Netherlands and the British Council of Churches for the continuation of its Mobile Medical Unit, which had been in place since 1969 and used among mountain villages. The unit was "staffed with a graduate university nurse, two doctors, a driver and a mountain evangelist." The letter of confirmation alludes to a number of difficulties associated with the development of the program. The most pressing of these challenges was the lack of public health education and standards of sanitation. Their initial health assessment indicated that "almost $100 \%$ of the people [had] worm infestations." In order to combat this, the program initiated a center for pest control and health education and screening. In addition, they hoped that funds

${ }^{41}$ Taiwan Black-foot Disease Socio-Medical Service Memorial House, King Ho Wang Culture and Arts Foundation http://www.blackfoot.org.tw/en/intro/ index.html

${ }^{42} \mathrm{CA} 2 / \mathrm{C} / 13 / 9$ Blackfoot Rehabilitation Training Project (22 June 1970) ${ }^{43} \mathrm{CA} 2 / \mathrm{C} / 13 / 9 \mathrm{Pu}$ Tai Community Development Project (11 April 1972). ${ }^{44} \mathrm{CA} 2 / \mathrm{C} / 13 / 9 \mathrm{Pu}$ Tai Community Development Project (11 April 1972). ${ }^{45}$ Tong Chunfa. Yuanzhumin jiaoyu yu Xinyang [Education and Religious belief among the Taiwan Indigenous people] YuShan Theological College \& Seminary Newsletter. 1999;6:59-112. 
could be raised to begin an agricultural program to enable villagers to increase their income and standard of living. ${ }^{46}$

The year's end report for the Taroko Community Development program in 1971 discusses the use of chemical fertilisers and insecticides as a better method of improving agricultural output in rice farming than the usual efforts of modifying machinery. ${ }^{47}$ In addition, the development programs proposed improving the drainage surrounding homes as a means of creating "a healthier place to live." Yet beneath this charitable veneer loomed a persistent infantilization of indigenous peoples: "To climax the year we planned an achievement day. This day was set aside to give the village people an opportunity to display their achievements of the past year. Samples of farm, garden and handicraft items were displayed and recognition was given for work well cone [sic]. We invited local church leaders to lead the village people in a service acknowledging that it is Christian love that prompted the planning, sponsoring and execution of this three year program." ${ }^{48}$

Over the course of the 1970s, agricultural programs and activities began to shift from large-scale improvement projects to educational scholarships. The Yu-shan Agricultural Scholarship offered three fivemonth scholarships for indigenous people. ${ }^{49}$ The course, originally taught at the Agricultural Training Centre, merged with the Yu-shan Theological Institute in Shoufeng in Hualien in 1972. ${ }^{50}$ In a letter from the Yu-shan Theological Institute in 1972, William Estell (acting principal) wrote the following: "There has been a very significant change in the tribal society of late. The profit margin for any type of agricultural work on Taiwan has diminished from past low to annual indebtedness in some cases, while expenditures have risen even in rural [areas] like in the mountains. The local government has seen this reflected in the loss of students in their 26 Agricultural schools throughout the island. They took action recently to assure themselves of having enough students for all the facilities and faculty now on hand by changing the name and function of those schools to incorporate both Agricultural training as well as vocational-small business training But we must recognize that there will continue to be a need for Agricultural training of a type which is both practical and not so highly theorectical [sic] that they are not prepared for making a living in the mountains." ${ }^{51}$

This shift of emphasis alluded to by the central government was part of a larger policy of using agriculture to foster industry that began in the 1950s under the Sino-American Joint Commission on Rural Reconstruction (JCRR, Zhongguo nongcun fuxing lianhe

${ }^{46} \mathrm{CA} 2 / \mathrm{C} / 15 / 10$ Tribal Mobile Clinic: Noordhoff to Jackson (11 March 1970). ${ }^{47} \mathrm{CA} 3 / \mathrm{A} / \mathrm{PAC} / 19$, Taiwan 09 Health Education Programme for East Coast Aborigines-1970-1972: Taroko Community Development Program 1971 Year End Report (1971).

${ }^{48} \mathrm{Ibid}$. This notion of "infantilising the natives" is well documented and often seen as a central constituent to colonial rule, see: Julia V. Emberley, Defamiliarizing the Aboriginal: Cultural practices and decolonization in Canada (Toronto: University of Toronto Press), 142; also, Achilleamillefolia, Infantilization of the Colonial Other, A Brooklyn Sabbatical (3 July 2014), http://brooklynsabbatical.wordpress.com/2014/07/03/infantilization-of-thecolonial-other/

${ }^{49} \mathrm{CA} 3 / \mathrm{A} / \mathrm{PAC} / 19$, Taiwan 11: Agricultural Scholarships for Tribal People: Yang to Williams (25 June 1973).

${ }^{50} \mathrm{CA} / \mathrm{A} / \mathrm{PAC} / 19$, Taiwan 11: Agricultural Scholarships for Tribal People: General Information (5 April 1972).

${ }^{51} \mathrm{CA} 3 / \mathrm{A} / \mathrm{PAC} / 19$, Taiwan 11: Agricultural Scholarships for Tribal People: Estell to Buma (10 February 1972). weiyuanhui). Aptly termed, "developing agriculture by means of industry and fostering industry by virtue of agriculture," has become synonymous with the three phases of land reform. ${ }^{52}$ Agricultural training continued in spite of this government shift. The Chin-Fong Mountain Community Development project was initiated in 1973 to extend the training programs to include three additional units. The first was the trial of an agricultural development unit, which included the planting of fruits (pears, tangerines and pineapples) as well as other crops (sugarcane, ginger, mushroom, peanuts and corn). The second unit, referred to as sanitation and medical aid, provided a service as opposed to a training program, targeting childhood measles and other family-planning services. The third program, entitled "home unit," was further subcategorized into pig farming, poultry rising and mushroom growing. ${ }^{53}$

By 1975, many of these programs merged into agricultural cooperatives and also began to appear in major Taiwan districts. In a report on agricultural cooperatives in Kaohsiung, the author outlines the motivation of the project as being to promote the socio-economic development of the rural society in Taiwan through the education and assistance in the organization of multi-purpose agricultural cooperatives. The total cost per annum amounted to NT $\$ 333,000$, with NT\$86,000 rose locally. In June 1973, the executive board of the Taiwan Ecumenical Industrial Ministry (TEIM) discussed the obstacles associated with rapid industrialization and the problems that an urban-industrial society brings to rural communities and economies. Believing that cooperatives were the best solution for improving the rural economy, the TEIM from August to December 1973 began a process of agricultural surveying..$^{54}$ One area of improvement that was noted was in irrigation and dike construction..$^{55}$

Projects on irrigation were first reported on 17 January 1970, with the completion of the Chu-keng Irrigation Project in Ilan County. Murray L. Garvin, Assistant Secretary to the Mountain Work Committee wrote in a letter to Rev. Alan Brush, Director of the Christian Aid Department, that he believed the project had been successful in a number of ways. The most obvious to him was the "significant" improvement the system was having on the standard of living of the people. What was more; he felt that the project had injected a general sense of drive among the villagers as they had contributed much of the labor. At the same time, it also seemed that the county government, "inspired by what the people and the church were doing, also joined the project and built part of the ditch." ${ }^{56}$ The establishment of the San Chung Student Counselling Centre in 1978 demonstrated a remarkable shift in how Christian Aid donations were used by the Taiwan Christian Services. The main purpose of the center was to provide assistance to students with mental and physical disabilities at various schools in the Sanchong triple area (an inner city district in the western part of New Taipei City, then Taipei County). The statement provided by TCS provides an important account of how the center was to be organized and operated, though it affords no description of how

${ }^{52}$ Niki J.P. Alsford, "Tea of Taiwan: Contemporary Adaptation", in Taiwan since Martial Law ed. David Blundell (Berkeley, CA \& Taipei: University of California and National Taiwan University Press, 2012), 267.

${ }^{53} \mathrm{CA} 3 / \mathrm{A} / \mathrm{PAC} / 19$, Taiwan 17: Chin-Fong Mountain Community Development: 2:2 (c.1975)

${ }^{54} \mathrm{CA} 3 / \mathrm{A} / \mathrm{PAC} / 19$, Taiwan 21: Agricultural Co-Operative: Agricultural Cooperative Promotion Programme, Kaohsiung (1975).

${ }^{55} \mathrm{CA} 3 / \mathrm{A} / \mathrm{PAC} / 19$, Taiwan 21: Agricultural Co-Operative: Huang to Kao (2 December 1971).

${ }^{56} \mathrm{CA} 2 / \mathrm{C} / 15 / 11$, Garvin to Brash (17 January 1970). 
they did operate. There is of course good reason to suppose that such centers never operated as smoothly or as rationally as their mission statements might suggest. Nevertheless, their aspirations included a short-range goal, which involved the recruitment of specialists in the field of psychology and social work; the middle-range goal was for the newly employed specialists to train voluntary social workers; and the final, long-range goal was for the center, through its efforts in the short and medium term, to solve "juvenile problems and reduce these problems so as to serve the purpose of the establishment of this Center." ${ }^{57}$ It is not entirely clear from the initial mission statement exactly how the center defined both mental health (phrased by them as a psychological handicap) and physical disability. A later report, along with the annual budget, does go into slightly more detail: "Owing to its specific geographical location and other factors, the population movement in Sanchung City is faster than in other cities in this country. Thus, a complicated social background has been formed and the students in Sanchung City are apparently influenced both physically and mentally. Their behaviour, such as destructiveness, disobedience, uncertainty of feeling, addiction to drugs, etc. has an adverse effect on education." ${ }^{58}$

For the purpose of discussion, I will take two things from this. First, something I feel is remarkable especially considering when it was established, is that in spite of a clear understanding of a feasible link between patterns of delinquency and urbanization (something that reformers of the late-19th and early 20th centuries had already alluded to) there still persisted this - almost eugenic - notion of criminal tendency being linked to mental health problems. ${ }^{59}$ The other point of discussion is that nowhere in the manifesto is there a mention of what physical disabilities they were supposedly assisting. And yet in terms of physical disability, the San Chung center was not the first in Taiwan to be sponsored by Christian Aid. The early 1970s also witnessed the initiation of the New Life Vocational Training Center. The center, whose students were categorized as being "handicapped," gave them the opportunity to supplement their income by interacting with their customers and taking personal orders for tailoring, watch/ clock repairs and woodcarving, all of which were carried out by the students. Photographs of the center clearly show physical disability, with students who were wheelchair-bound or using crutches. Each month, two meetings were scheduled and an annual summer camp was organized and held at Fulong beach in Gongliao (New Taipei City) which was attended by all students and staff members as well as the Keelung Central Lions Clubs [Jilong zhongyang shizihui Keelung Central Lions Club (part of the international, Chicago-based Lions Clubs International) and the YMCA in Taipei. ${ }^{60}$

Christian Aid and UNITAS-funded project called Local Power was initiated, primarily as a lobby group for the economic, social and cultural rights of people living with disabilities. ${ }^{61}$ A similar

\footnotetext{
${ }^{57}$ CA3/A/PAC/19, Taiwan 11: Agricultural Scholarships for Tribal People: San Chung Students Counseling Center, TCS (22 November 1978).

${ }^{58}$ CA3/A/PAC/19, Taiwan 11: Agricultural Scholarships for Tribal People: Sanchung City Student Counselling Project (1978).

${ }^{59}$ Arnold Binder \& Gilbert Geis, Juvenile Delinquency: Historical, cultural and legal perspectives, third edition (Cincinnati, OH: 2000) 45; also, Michae A. Rembis, Defining Deviance: Sex, science, and delinquent girls, 1890-1960 (Champaign, IL: University of Illinois Press, 2011), and Pamela Cox, History and Global Criminology: (re)inventing delinquency in Vietnam, The British Journal of Criminology 52 (2012): 17-31.

${ }^{60} \mathrm{CA} 2 / \mathrm{C} / 13 / 9$, Hsia to Doll (10 April 1974).

${ }^{61} \mathrm{CA}$. Fighting Disability Discrimination in Bolivia
}

Christian Aid-funded initiative was also delivered in partnership with the Lebanese Physically Handicapped Union (LPHU) and the East Jerusalem YMCA. Again, this was essentially a lobbying group, with money used to improve job prospects and current working conditions and to raise awareness of issues faced by people with disabilities. ${ }^{62}$ Christian Aid-sponsored centers such as these also provided benefaction to help raise the standard level of education across the spectrum of society, in the belief that education is the key to tackling poverty ${ }^{63}$ Projects initiated by Christian Aid to raise the standard of education, particularly among Taiwan's indigenous peoples in the post-war period, can be seen as far back as 1966 when the thenPresbyterian Church of Formosa, in a correspondence with the British Council of Churches Christian Aid Department on 21 November 1966, confirmed the receipt of monies forwarded to them for a scholarship for "needy Christian tribal students." In their report they confirmed that 75 students were enrolled at junior and senior middle schools through scholarship donations. Donald J. Wilson (Associate General Secretary) further reiterated the importance of funding and the increase in the number of indigenous students taking the entrance exam: "This group has steadily increased in size and we are proud of it growing number. As you may know, through this program our church has been able to offer better educational opportunities to the cultural minorities in Taiwan through scholarship aid for worthy and promising tribal students. With the limited resources available, we can only help a few of those who apply. This year 430 tribal students took the entrance exam but we were only able to accept $32 .{ }^{\prime 64}$ Furthermore, Wilson hoped that with further aid they would be able to provide university scholarships for those wishing to further their education. On 12 March 1970, the now-General Assembly of the Presbyterian Church of Taiwan (PCT) confirmed receipt (through TCS) of a grant for scholarship aid for students attending universities. ${ }^{65}$ Two indigenous groups that were often targeted in such development projects were the Paiwan and Rukai in Taitung County on the eastern coast of Taiwan. The Chin-Fong Mountain Community Development program, which was discussed earlier, earmarked three villages for development in a collaborative project involving Taiwan Christian Services and the local government. A report prepared in September 1971 by the district office, TCS and the Tainan Theological College indicated: "That the general economic and social situation in this community is still fairly backward. The economic life of the area was found to be bad, sanitation poor, agricultural knowledge inadequate, housing crude, communication with the outside difficult, medical facilities lacking; also there was little evidence of business ability or side occupations, fleecing by outsiders selling retail merchandise was serious, the local people were not accustomed to saving money, did not consider education important, had no vocational education and thus had few opportunities for outside employment, drank far too much." ${ }^{66}$ Underneath this seemingly universal stereotypical view of indigenous peoples, global trends of social movements for human rights and the proclamation to protect and elevate cultural and ethnic identities (especially of indigenous peoples) in the 1970s saw Canada

http:/www.christianaid.org.uk/whatwedo/eyewitness/americas/fightingdisability-discrimination-in-bolivia.aspx

${ }^{62} \mathrm{CA}$. Overcoming Barriers (Middle East) http://www.christianaid.org.uk/ getinvolved/communitypartnership/middle-east.aspx

${ }^{63} \mathrm{CA}$. Education, http://www.christianaidcollective.org/resources/education ${ }^{64} \mathrm{CA} 2 / \mathrm{C} / 15 / 8$ Wilson to British Council of Churches (21 November 1966). ${ }^{65} \mathrm{CA} 2$ Garvin to Littlewood (12 March 1970).

${ }^{66} \mathrm{CA} 3 / \mathrm{A} / \mathrm{PAC} / 19$, Taiwan 17: Chin-Fong Mountain Community Development: Progress Report to CICARWS (10 September 1973). 
solidifying then-Prime Minister Pierre Elliot Trudeau's 1971 "liberal version of multiculturalism"; the 1979 Aboriginal Treaty Committee's push for "self-determination" among Australian Aborigines; the Māori protest movements from the 1975 land march; and in Taiwan, pressure for political change came through the Tangwai movement. ${ }^{67}$

\section{Taiwan's political situation}

The 1970s in the political history of Taiwan, like much of the globe, was a decade best described as a "pivot of change." Social progression that had begun in the preceding decade globally opened then in greater force. The decade saw significant progress in the number of women as heads of state and governments. Soong Chingling continued as first chairwoman of the PRC until 1972, Isabel Martines de Peron became the first female president of Argentina in 1974, Indira Gandhi continued as prime minister of India until 1977, Elizabeth Domitien took office as first female prime minister of the Central African Republic in 1975 and Margaret Thatcher and Maria de Lourdes Pintasilgo became the first female prime ministers of the United Kingdom and Portugal respectively in 1979. In China, US President Richard Nixon's visit in 1972 (a year after Henry Kissinger's "secret" visit) saw the beginnings of normalization of relations between the two countries. In 1976, with the deaths of both Mao Zedong and Zhou Enlai, a new era began in the PRC as Deng Xiaoping emerged as China's "new" leader. The new international context created in the 1970s thus enlarged, according to Denny Roy, the continuation of the Chinese Civil War into a war of global significance. ${ }^{68}$ Perhaps most significant was the change of China's seat as permanent member of the United Nations Security Council. With the adoption of Resolution 2758 on 25 October 1971, the UN General Assembly recognized the PRC as the only legitimate and lawful representative of China. The decade saw a significant number of countries switching diplomatic recognition following the vote and by the end of the decade the number of countries recognizing the ROC had dropped to $26 .{ }^{69}$ In spite of Nixon's now famous line "I will never sell you down the river," delivered to Chiang Ching-kuo during his visit to Washington in April 1970, suspicion grew in Taipei over US rapprochement with the PRC. Yet such concern quickly turned to shock upon hearing news of Kissinger's visit to Beijing and the US informed Taipei only 20 minutes before Nixon's famous broadcast. ${ }^{70}$ Along with the international "pivot of change," grassroots processes as well as economic transitions also gained significant ground in Taiwan during the 1970s. As oil prices hiked, leading to economic decline

${ }^{67}$ Scott Simon, Multiculturalism and Indigenism: Contrasting the experiences of Canada and Taiwan, in Politics of Difference in Taiwan eds. Tak-wing Ngo, and Hong-zen Wang (London: Routledge, 2011), 21; V. Burgmann, The Aboriginal Movement in Power, Profit and Protest: Australian social movements and globalisation (Sydney: Allen \& Unwin, 2003), 45-6; and Rawiri Taonui, Ngā tuakiri hōu - new Māori identities - Māori renaissance, Te Ara - the Encyclopaedia of New Zealand, (18 September 2013), http://www. teara.govt.nz/en/nga-tuakiri-hou-new-maori-identities/page-3 also, Michael Stainton, Aboriginal Self-government: Taiwan's uncompleted agenda, in Taiwan: A new history, ed. Murray Rubinstein (Armonk, NY: M.E. Sharpe, 1999), 419-436.

${ }^{68}$ Denny Roy, Taiwan: A political history (Ithaca, NY: Cornell University Press, 2003), 105

${ }^{69} \mathrm{See}$, woguo yu shijie geguo guanxi yilanbiao, (List of ROC relations with other countries) in Zhonghua minguo bashibanian waijiao nianjian, [Yearbook of Foreign Affairs Yearbook, Republic of China, 1999]. http://multilingual. mofa.gov.tw/web/web_UTF-8/almanac/almanac1999/attach/chapter52.htm. ${ }^{70}$ Roy, 131. (the oil crises of 1973 and 1979) in the developed world, economic growth in export-driven countries like the Four Asian Tigers (Taiwan, Hong Kong, South Korea and Singapore) resulted in rapid economic transformation and industrialization. ${ }^{71}$

The late 1970s saw the emergence of a civil society in Taiwan with mass protests against the state of martial law that had been in place since 19 May, $1949 .{ }^{72}$ Opposition forces began to gather strength in the 1970s and then-President Chiang Ching-kuo made attempts to recruit Taiwanese into the ruling party. This quest for political equality in turn manifested itself in the growth of popular social movements eager for political liberalization that would eventually lead to a process of democratization, which, according to David Blundell, gave "Taiwan a heartfelt sense of local identity from the $1970 \mathrm{~s}$ " onwards. ${ }^{73}$ During the final year of the decade, this burgeoning 'sense of self' was expressed in the uprising known as the Kaohsiung Incident or meilidao shijian Beautiful Island Event. In an effort to promote democracy in Taiwan, opposition politicians including the Kaohsiung Eight (Chang Chunhung, Huang Shin-Chieh, Chen Chu, Yao Chia-wen, Shih Ming-teh, Annette Lu, Lin Yi-hsiung and Lin Hung-hsuan) held a demonstration commemorating Human Rights Day. ${ }^{74}$ Between 2 and 3 o'clock on the afternoon of 10 December 1979, the military and non-military police, as well as the army, moved into position before the demonstrators arrived. That evening, as the military closed in, the demonstrators and military finally clashed. The authorities subsequently used the incident to arrest known opposition leaders. From March to April 1980, the Kaohsiung Eight were tried in a military court and given sentences that ranged from 12 years to life imprisonment. ${ }^{75}$ Ten people connected with the Presbyterian Church of Taiwan were also tried for hiding Shih Ming-teh. Most prominent was Kao Chun-ming, the General-Secretary of the PCT, who was sentenced to seven years in prison. ${ }^{76}$

Shortly after eight in the evening on Thursday 24 April, local police called on Kao's house. Almost immediately afterwards, six Garrison Command police (Taiwan jingbei zongsilingbu-Taiwan garrison command headquarters) searched his premises and confiscated a number of items. An hour or so later, Kao was taken away and all communication with his residence was cut off. At 11 p.m., local television, as well as the Police Broadcasting (jingcha guangbo diantai Police Radio), reported that Kao had been arrested after being indicted for his involvement in harboring a fugitive (Shih Ming-

${ }^{71}$ On the Taiwan economic miracle Taiwan Qiji Taiwan miracle, see Thomas B. Gold, State and Society in the Taiwan Miracle (Armonk, NY: M.E. Sharpe, 1986). ${ }^{72}$ Martial law was lifted 15 July 1987.

${ }^{73}$ David Blundell, Taiwan Coming of Age, in Taiwan Since Martial Law ed. David Blundell (Berkeley, CA \& Taipei: University of California and National Taiwan University Press, 2012), 4.

${ }^{74}$ Tang Chih-Chieh. Shibukemian de chungtu: cun jiegou/guocheng de bianzheng kan meilidao shijian zhi fasheng [An Unavoidable Conflict: An Explanation of the Kaohsiung Incident in Terms of the Dialectic of Structure and Process]. Taiwanese Sociology. 2007;13:71-128.

${ }^{75}$ The following months saw an additional thirty-three (Kaohsiung 33) people involved in the Human Rights Day gathering tried in a civil court. Sentences for them ranged from 2 to 6 years.

${ }^{76}$ Shih Ming-teh received a life-sentence and his wife Linda Arrigo was deported back to the US, Roy, 169; Fell, 176; and J. Bruce Jacobs, The Kaohsiung Incident in Taiwan and Memoirs of a Foreign Big Beard (Leiden: BRILL, 2016), 87. Also, PCE/FMC, V,8:1, Rev. Bernard G. Thorogood to the Editor of the Times Newspaper, (9 June 1980). 
teh). ${ }^{77}$ The arrest of the General Secretary of the PCT prompted a stiff reaction among global Church leaders. Father Michael McHugh, at the Commission for International Justice and Peace (CIJP) in London, received a letter expressing gratitude for the interest that the Catholic bishops had shown toward the Taiwan situation and arrest of Kao. In spite of the "different line" that the Catholic Church in Taiwan held under Bishop Luo Kuang and the public statements that were made by him against the actions of the PCT, he had felt great sympathy with the position of the Taiwanese people and the PCT. ${ }^{78}$ The Council for World Mission on 6 June 1980 wrote to President Chiang Ching-kuo on behalf of 27 churches to seek clemency for Kao. ${ }^{79}$ A similar appeal was written by the British Council of Churches, the World Alliance of Reformed Churches and the National Council of Churches in India. ${ }^{80}$ In the summer of 1984 Kao Chun-ming was released from the Green Island political-prison facility Ludao shanzhuang. ${ }^{81}$ During his incarceration, his wife Ruth Kao helped organize international support for human rights in Taiwan. In 2000, following the election of Chen Shui-bian, Kao was appointed Senior Advisor to the Presidential Office $^{82}$

\section{Towards a transnational understanding of christian aid to taiwan}

In the eyes of sociologist Charles Tilly, social movements provide a major vehicle for ordinary people's participation in public politics. ${ }^{83}$ With a focus that is often specific to either a political or social issue, social movements are not static, but forever evolving. Some achieve success, while others do not. Often they are local in context and at times they merge with similar global trends. Discourse on the Sunflower Movement's action of occupying the lifayuan has, rightly or wrongly, merged with the global Occupy Movement. ${ }^{84}$ The Christian

${ }^{77} \mathrm{PCE} / \mathrm{FMC}, \mathrm{V}, 8: 1$, Arrest of Rev. Dr. C.M. Kao, Office for East Asia and the Pacific (24 April 1980).

${ }^{78} \mathrm{PCE} / \mathrm{FMC}, \mathrm{V}, 8: 1$, Letter to Father Michael McHugh (22 May 1980).

${ }^{79} \mathrm{PCE} / \mathrm{FMC}, \mathrm{V}, 8: 1$, The Council for World Mission, Thorogood to Chiang (6 June 1980).

${ }^{80} \mathrm{PCE} / \mathrm{FMC}, \mathrm{V}, 8: 1$, For Immediate Release: General Secretary of Taiwan Church Imprisoned (17 June 1980); PCE/FMC, V,8:1, World Alliance of Reformed Churches, Perret to Anderson (30 April 1980); PCE/FMC, V,8:1, National Council of Churches in India, Ratnam to Scopes (13 October 1981).

${ }^{81}$ Murray A. Rubinstein, Political Taiwanization and Pragmatic Diplomacy: The eras of Chiang Ching-kuo and Lee Teng-hui, 1971-1994, in Taiwan: A new history, ed. Murray Rubinstein (Armonk, NY: M.E. Sharpe, 1999), 444; and Hu Huiling, Shizijia zhi ru: kaojunming mushi huivilu, [A road of the cross: Memoirs of priest Kao Chun-ming] (Taipei: Spring Wind Media, 2001).

${ }^{82}$ Shieh Ta-Lih. Jianzheng shidai de endian zuji: gaolilizhen mushi koushu shilu [Witnessing the footprint of Blessing over the times: Mrs. Kao Lee Li-chen's oral Record].Taipei: Taiwan Theological College Press, 2010), 278-81.

${ }^{83}$ Charles Tilly, Social Movements, 1768-2004 (Boulder, CO: Paradigm Publishers, 2004), 3.

${ }^{84}$ Lorand C. Laskai, The Transformation of Taiwan's Sunflower Movement, The Diplomat (5 May 2014), http://thediplomat.com/2014/05/the-transformationof-taiwans-sunflower-movement/; Ian Rowen, Inside Taiwan's Sunflower Movement-Where Asia's Largest Student Uprising is Blooming, Occupy Wall Street (n.d.), http://occupywallstreet.net/story/inside-taiwans-sunflowermovement- $\% \mathrm{E} 2 \% 80 \% 93$-where-asias-largest-student-uprising-blooming and Kerim Friedman, Sunflower Movement, Savage Minds: Notes and queries in Anthropology (22 March 2014).
Aid-funded movement in the 1970 s, though not a social movement in the real sense, targeted three of the major issues that spurred social movements in Taiwan: education, health and environment. This analysis shows its efforts to assist Taiwan-based voluntary organizations in their quest to improve the lives of others. However, in doing so, the very people they were counseling were often silenced. In doing so, the Christian Aid-funded movement spoke for, rather than with, the people most in need of their advocacy. Their efforts were marred by trampling on the people's rights for self-determination.

A good example of this is the development projects among indigenous communities. In the Orchid Island Project, for instance, it is clear that major efforts were made to encourage the continuation of such intangible cultural heritage as boat building, pottery and other handicrafts. Still, there was little, if any, effort made to understand the cultural taboos associated with certain agricultural cultivation practices and the community's self-regulated fishing areas, timing and methods. ${ }^{85}$ The 1970s, that "decade of pivotal change," is an important point of reference for any discussion of social movements in Taiwan. It was a decade that witnessed great changes in the political history of Taiwan as well as in the clout of Christian Aid to campaign on global political issues. By focusing on this period in Taiwan's social history it is possible to identify subtle similarities between presentday social movements and the efforts made by the Christian Aidfunded local institutions. By analyzing the archives in this way, this chapter allows one to see the details of individuals involved in the movement in everyday life experiences. It was here that the ideologies of the local institutions interacted with the social issues of the time. Only on this level was it possible to see how the efforts for or against social change was put into practice. Hopefully, by addressing this often overlooked aspect of the history of social movements in Taiwan, this paper has contributed to the growing debate on Taiwanese social movements, rights discourses and citizenship. The role of Christian Aid, whose presence in Taiwan consisted solely of funded projects made through local structures, provides an interesting case for future comparative research that may have a transnational focus on aid relief and campaign agendas.

\section{Acknowledgements}

None.

\section{Conflict of interest}

Author declares there is no conflict of interest.

${ }^{85} \mathrm{CA} 3 / \mathrm{A} / \mathrm{PAC} / 19$, Taiwan 12 Orchid Island Project: Chang to Buma (18 April
1972). 